JURNAL ILMIAH TEKNOLOGI INFORMASI DAN KOMUNIKASI (JTIK) VOL 12, No.2, September 2021, pp. $74-83$

p-ISSN : 2087-0868 (media cetak)

e-ISSN : 2598-9707 (media online)

http://ejurnal.provisi.ac.id/index.php/JTIKP

page 74

\title{
Rancang Bangun Sistem Informasi Penjualan Online Berbasis Web Mobile Dengan Pendekatan Waterfall
}

\author{
Arditya Himawan ${ }^{1}$, Migunani ${ }^{2}$ \\ ${ }^{1}$ Universitas Sains dan Teknologi Komputer \\ Jl. Majapahit 605 Semarang, Telp. (024) 6723456, e-mail: arditya_himawan@yahoo.com \\ ${ }^{2}$ Universitas Sains dan Teknologi Komputer \\ Jl. Majapahit 605 Semarang, Telp. (024) 6723456, e-mail: migunani@ gmail.com
}

\begin{tabular}{l}
\hline ARTICLE INFO \\
\hline \\
Article history: \\
Received : 28 - Agustus - 2021 \\
Received in revised form : 7 - September - 2021 \\
Accepted : 11 - Oktober - 2021 \\
Available online : 16 - Oktober - 2021
\end{tabular}

\begin{abstract}
PT XYZ is a computer shop engaged in the sale of laptops, computers, spare parts, accessories supporting and providing repair services. The marketing process is less than optimal because it only sells by phone or social media. There are some problems that occur between them : (1) Stock management is not optimal because of frequent discrepancies between stock records with the amount of goods available so often consumers feel disappointed with the services provided, (2) The issue of uploaded ad duration in uploaded social media will alternate from one product content display to another in a relatively short period of time, (3) The absence of management of consumer sales transactions thus requiring recording of repeated transactions, (4) The decline in sales turnover in recent months (5). The management of customer or consumer data is less noticed. Based on these problems, this study aims to design a webbased online sales information system mobile on PT XYZ . This research uses the development of SDLC waterfall model system which consists of planning, analysis, design, implementation and maintenance. Using PHP and MySQL Server programming language as database. The results of research in the form of Online Sales Information System WebBased Mobile that can facilitate consumers to view products, make reservations for consumers and management for the admin. This information system is equipped with product management features, order data management, customer data management, preparing order reports and payment confirmation. So that this information system can provide convenience both consumer and admin on PT XYZ
\end{abstract}

Keywords: Online Sales, PT XYZ, Web Mobile, Waterfall, UML

\section{PENDAHULUAN}

Teknologi internet kini sudah tidak asing lagi, kebutuhan masyarakat akan informasi yang cepat sangatlah mudah, dapat diakses oleh siapa saja, kapan saja dan di mana saja. Teknologi internet mempunyai 
efek yang sangat besar pada perdagangan atau bisnis. Dapat mengakses informasi barang dari mana saja baik dari harga, spesifikasi, dan melakukan transaksi pembelian. Hal ini sangat menghemat waktu dan biaya bagi calon pembeli, karena tidak perlu datang ke toko atau tempat transaksi sehingga dari tempat duduk saja mereka dapat mengambil keputusan dengan cepat. PT XYZ merupakan sebuah toko komputer yang bergerak dibidang penjualan laptop, komputer, spare part, accessories pendukungnya dan menyediakan pelayanan jasa perbaikan. Proses pemasaran yang kurang optimal karena hanya melakukan penjualan melalui telepon ataupun sosial media. terdapat beberapa masalah yang terjadi diantara nya (1) Manajemen stok belum optimal karena sering terjadi ketidaksesuaian antara catatan stok dengan jumlah barang yang tersedia sehingga sering kali konsumen merasa kecewa dengan pelayanan yang diberikan. (2) Masalah durasi tayang iklan di sosial media yang diunggah akan silih berganti dari satu tayangan konten produk ke konten produk yang lain dalam waktu yang relatif singkat. (3) Tidak adanya pengelolaan terhadap transaksi penjualan konsumen sehingga mengharuskan pencatatan transaksi yang berulang-ulang. (4) Terjadinya penurunan omset penjualan dalam beberapa bulan terakhir. (5) Manajemen data pelanggan atau konsumen kurang diperhatikan.

Melihat kondisi tersebut maka diperlukan langkah-langkah diantaranya (1) Melakukan manajemen stok yang berkala agar antara catatan stok dan jumlah barang sesuai. (2) Perlunya pembuatan dan pengelompokan pada produk-produk yang dijual sehingga konten produk yang sudah di unggah tidak hilang begitu saja setelah durasi waktu tertentu. (3) Perlunya manajemen katalog produk yang baik agar produk-produk yang ditawarkan kepada calon pembeli bersifat persisten atau tahan lama. Dengan manajemen produk yang baik maka permasalahan terkait dengan penambahan dan pembaharuan produk dapat teratasi. (4) Perlunya Manajemen transaksi untuk mencatat setiap transaksi yang terjadi sehingga akan memudahkan penelusuran terhadap histori transaksi dari konsumen serta (5) Melakukan manajemen data pelanggan atau konsumen akan memudahkan pemilik usaha menjalin hubungan dengan konsumenya. Penawaran atau promosi produk baru, produk diskon dan cuci gudang maka pemilik usaha akan dengan mudah menginformasikan kepada para konsumenya.

Berdasarkan uraian latar belakang tersebut, perlu adanya sebuah sistem informasi penjualan online berbasis web mobile yang dapat memberikan pelayanan yang lebih cepat kepada konsumen serta dapat memudahkan admin dalam melakukan pengelolaan produk serta transaksi penjualan di PT XYZ . Maka dilakukan penelitian dengan judul "Rancang Bangun Sistem Infomasi Penjualan Online Berbasis Web Mobile (Studi Kasus PT XYZ Semarang)..

\section{TINJAUAN PUSTAKA}

\section{A. Sistem}

"Sistem adalah suatu jaringan kerja dari prosedur-prosedur yang berhubungan, terkumpul bersamasama untuk melakukan suatu kegiatan atau tujuan tertentu"[17]. Bahwa sistem dapat di artikan sebagai suatu kumpulan atau himpunan dari unsur, komponen, atau variabel yang terorganisir, saling berinteraksi, saling bergantung satu sama lain, dan terpadu[13].

\section{Karakteristik Sistem}

"Model umum sebuah sistem adalah input, proses, dan output. Hal ini merupakan konsep sebuah sistem yang sangat sederhana sebab sebuah sistem dapat mempunyai beberapa masukan dan keluaran. Selain itu, sebuah sistem mempunyai karakteristik atau sifat-sifat tertentu yang mencirikan bahwa hal tersebut bisa dikatakan sebagai seuatu sistem"[13]. Adapun karakteristik yang dimaksud antara lain sebagai berikut:

a. Komponen Sistem (Components)

Suatu sistem terdiri dari sejumlah komponen yang saling berinteraksi, artinya saling bekerja sama membentuk satu kesatuan. Komponen-komponen sistem tersebut dapat berupa suatu bentuk subsistem. Setiap subsistem memiliki sifat dari sistem yang menjalankan suatu fungsi tertentu dan mempengaruhi proses sistem secara keseluruhan. Suatu sistem dapat mempunyai sistem yang lebih besar atau sering disebut "supra sistem".

b. Batasan Sistem (Boundary)

Ruang lingkup sistem merupakan daerah yang membatasi antara sistem dengan sistem yang lain atau sistem dengan lingkungan luarnya. Batasan sistem ini memungkinkan suatu sistem dipandang sebagai satu kesatuan yang tidak dapat dipisahkan.

c. Lingkungan Luar Sistem (Environment)

Bentuk apapun yang ada diluar ruang lingkup atau batasan sistem yang mempengaruhi operasi sistem tersebut disebut lingkungan luar sistem. Lingkungan luar sistem ini dapat bersifat menguntungkan dan dapat juga bersifat merugikan sistem tersebut. Dengan demikian, lingkungan luar tersebut harus tetap dijaga dan dipelihara. Lingkungan luar yang merugikan harus dikendalikan. Kalau tidak, maka akan mengganggu kelangsungan hidup sistem tersebut. 
d. Penghubung Sistem (Interface)

Media yang menghubungkan sistem dengan subsistem yang lain disebut penghubung sistem atau interface. Penghubung ini memungkinkan sumber-sumber daya mengalir dari satu subsistem ke subsistem lain. Bentuk keluaran dari satu subsistem akan menjadi masukan untuk subsitem lain melalui penghubung tersebut. Dengan demikian, dapat terjadi suatu integrasi sistem yang membentuk satu kesatuan.

e. Masukan Sistem (Input)

Energi yang dimasukkan ke dalam sistem disebut masukan sistem, yang dapat berupa pemeliharaan (maintenance input) dan sinyal (signal input). Contoh, di dalam suatu unit sistem komputer, "program" adalah maintenance input yang digunakan untuk mengoperasikan komputernya dan "data" adalah signal input untuk diolah menjadi informasi.

f. Keluaran Sistem (Output)

Hasil energi yang diolah dan diklasifikasikan menjadi keluaran yang berguna. Keluaran ini merupakan masukan bagi subsistem yang lain seperti sistem informasi. Keluaran yang dihasilkan adalah informasi. Informasi ini dapat digunakan sebagai masukkan untuk pengambilan keputusan atau hal-hal lain yang menjadi input bagi subsistem lain.

g. Pengolah Sistem (Proses)

Suatu sistem dapat mempunyai suatu proses yang akan mengubah masukan menjadi keluaran, contohnya adalah sistem akuntansi. Sistem ini akan mengolah data transaksi menjadi laporanlaporan yang dibutuhkan oleh pihak manajemen.

h. Sasaran Sistem (Objective)

Suatu sistem mempunyai tujuan dan sasaran yang pasti dan bersifat deterministic. Kalau suatu sistem tidak memiliki sasaran maka operasi sistem tidak ada gunanya. Suatu sistem dikatakan berhasil bila mengenai sasaran atau tujuan yang telah direncanakan.

\section{B. Informasi}

Informasi adalah data yang telah diolah menjadi bentuk yang berarti bagi penerimanya dan bermanfaat dalam menggambil keputusan saat ini atau mendatang[12]. Informasi adalah data yang diolah menjadi bentuk yang lebih berguna dan lebih berarti bagi yang menerimanya para ahli lain memberikan definisi yang hampir serupa bahwa informasi adalah data yang telah diolah menjadi sebuah bentuk yang berarti bagi penerimanya dan bermanfaat bagi pengambil keputusan saat ini maupun dimasa yang akan datang[1]. Sehingga sistem informasi adalah kombinasi dari teknologi informasi dan aktivitas orang yang menggunakan teknologi itu untuk mendukung operasi dan manajemen. sistem informasi adalah sistem yang dapat didefinisikan dengan mengumpulkan, memproses, menyimpan, menganalisis, menyebarkan informasi untuk tujuan tertentu. Seperti sistem lainnya[14]. sebuah sistem informasi terdiri dari input (data instruksi) dan output (laporan, kalkulasi). "Sistem informasi adalah kumpulan perangkat keras dan perangkat lunak yang dirancang untuk mentransformasikan data ke dalam bentuk informasi yang berguna"[3].

\section{Penjualan}

Penjualan adalah "Pendapatan yang berasal dari penjualan produk perusahaan, disajikan setelah dikurangi potongan penjualan dan retur penjualan"[11]. "Penjualan bersih merupakan selisih antara penjualan baik yang dilakukan secara tunai maupun kredit dengan retur penjualan dan potongan penjualan"[10] Pemesanan adalah proses, perbuatan, cara memesan atau memesankan. Suatu aktifitas yang dilakukan oleh konsumen sebelum membeli. Kemajuan teknologi sekarang ini memungkinkan pemesanan tidak hanya dapat dilakukan jika konsumen dan penjual bertatap langsung, tetapi dapat dilakukan dari jarak jauh sekalipun, misalnya dengan menggunakan E-commerce, yaitu sistem pemesanan barang lewat internet. Untuk mewujudkan kepuasan konsumen maka perusahaan harus mempunyai sebuah sistem pemesanan yang baik[6]. Pemesanan adalah proses, perbuatan, cara memesan atau memesankan[2].

Perlunya manajemen persediaan barang untuk memudahkan pengelolaan barang bersedian. "Persediaan adalah barang-barang yang disimpan untuk digunakan atau dijual pada masa yang akan datang[9]. Pada umumnya, persediaan (inventory) merupakan barang dagangan yang utama dalam perusahaan dagang. Persediaan termasuk dalam golongan aset lancar perusahaan yang berperan penting dalam menghasilkan laba perusahaan. Secara umum istilah persediaan dipakai untuk menunjukkan barangbarang yang dimiliki untuk dijual kembali atau digunakan untuk memproduksi barang-barang yang akan dijual. Dalam perusahaan dagang, persediaan merupakan barang-barang yang diperoleh atau dibeli dengan tujuan untuk dijual kembali tanpa mengubah barang itu sendiri.

JURNAL ILMIAH TEKNOLOGI INFORMASI DAN KOMUNIKASI (JTIK) VOL 12, No.2, September 2021, pp. 74 - 83 


\section{Web Mobile}

Mobile web secara sederhana menjadikan World Wide Web (WWW) dapat diakses melalu perangkat mobile, berkembang dari telepon seluler biasa ke generasi smartphones[4]. Hal ini meliputi keseluruhan isi web dan tidak dibatasi untuk website yang memang khusus didesain untuk dilihat secara mobile (WAP Wireless Application Protocol). Keuntungan dari mobile web antara lain yaitu:

1. Constant Connectivity - Dengan adanya mobile web pemilik perangkat smartphones bisa mengakses informasi setiap waktu dan tempat.

2. Location-Aware - Banyak dari smartphones sekarang mempunyai GPS (Global Positioning System), hal ini membuat para pengguna smartphones lebih 'peduli' dengan posisi mereka. Pengguna bisa mencari lokasi,menemukan arah tujuan, dan lain-lain.

3. Limitless Access - Mengakses mobile web sama seperti mengakses website secara penuh. Pengguna bisa mendapatkan sumber daya yang sama dengan yang mereka dapatkan saat menggunakan komputer desktop.

4. Interactive Capabilities - Pengguna mobile web di tawarkan dengan pengalaman membaca/menulis pada web dalam genggaman tangan meraka. Pengguna bisa melakukan berbagai aktifitas online sama seperti saat menggunakan komputer desktop.

\section{METODOLOGI PENELITIAN}

Metode pengembangan sistem yang digunakan dalam penelitian rancang bangun sistem informasi penjualan online berbasis web mobile menggunakan Software Development Life Cycle (SDLC) dengan tahapan-tahapan sebagai berikut:

\section{Tahap Perencanaan Sistem (System Planning)}

a. Mendefinisikan masalah

Masalah yang umum terjadi pada penelitian di PT XYZ adalah sistem penjualan dan ketersediaan barang yang sering terjadi.

b. Tujuan dan Manfaat

Tujuan dan manfaat dari perancangan sistem informasi penjualan online berbasis web mobile yaitu karena banyak pengguna smartphone/perangkat mobile serta untuk mengatasi masalah dan memberikan solusi terhadap permasalahan yang ada pada sistem pelayanan di PT XYZ, khususnya pada sistem penjualan, serta dapat menghasilkan sebuah sistem yang dapat membantu proses pemesanan yang lebih efektif, sehingga memudahkan admin untuk mengelola PT XYZ dalam pencatatan laporan penjualan serta keuangan.

\section{Tahap Analisis Sistem (System Analysis)}

\section{a. Analisis Data dan Informasi}

Data-data yang dibutuhkan dalam penelitian sebagai berikut:

1) Data Jenis Produk dan Harga Produk di PT XYZ

2) Data Konsumen yang berupa Identitas pelanggan, alamat email dan nomor telepon

3) Informasi Data Diri Perusahaan, seperti nama, alamat perusahaan dan nomor telepon

4) Informasi Transaksi pemesanan dan pembayaran oleh konsumen kepada pihak PT XYZ

\section{b. Analisis Sistem Lama}

Menganalisis kelemahan sistem yang ada dengan menggunakan usecase dan activity diagram. Prosedur dalam pemesanan di PT XYZ yaitu konsumen melakukan telepon terlebih dahulu, kemudian menanyakan barang yang mereka cari, penjual akan menjelaskan detail barang dan ketersediaan barang. Setelah terjadi kesepakatan antara kedua belah pihak, penjual akan menyediakan barang dan menuliskan nota pembelian, kemudian konsumen datang ke toko untuk mengambil barang dan melakukan pembayaran terhadap barang tersebut. Berikut ini adalah gambaran sistem yang sedang berjalan. ditunjukkan pada gambar 3.1

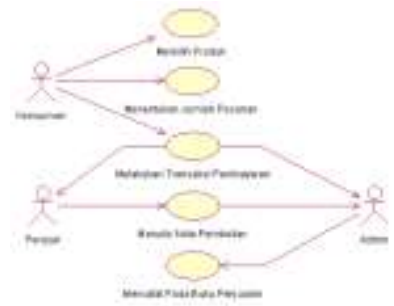

Gambar 3.1 Use Case Diagram Sistem Lama

\section{c. Gambaran Sistem Baru}


Diharapkan sistem baru dapat membantu mengatasi permasalah yang terdapat pada sistem yang lama. Sistem Informasi Penjualan Online berbasis Web Mobile dirancang untuk mempermudah melakukan pemesanan, pencatatan data para konsumen, dan mempermudah penyampaian informasi produk kepada para konsumen.

\section{Tahap Perancangan Sistem (System Design)}

\section{a. Pemodelan Proses}

Penerapan pemodelan proses pada sistem informasi penjualan online berbasis web mobile secara garis besar yang melibatkan aktor dalam sistem. Activity diagram menjelaskan alur sistem dan semua aktifitas yang dilakukan aktor dan sistem.

(1). Use Case Diagram Konsumen

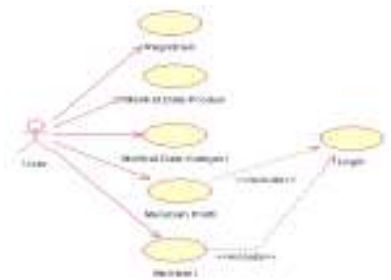

Gambar 3.3 Use Case Diagram Konsumen

Dijelaskan pada gambar 3.3 bahwa user dapat melihat data produk dan data kategori tanpa harus melakukan login terlebih dahulu, Sedangkan untuk merubah profil dan membeli, user harus melakukan login terlebih dahulu. Dan registrasi digunakan user untuk melakukan pendaftaran.

(1). Activity Diagram Registrasi User

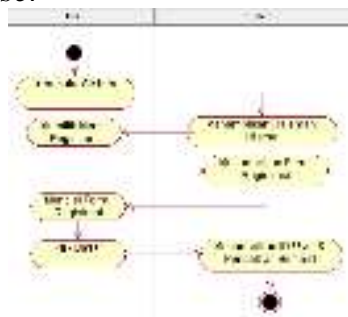

Gambar 3.11 Activity Diagram Registrasi User

Dijelaskan bahwa user membuka sistem, sistem akan menampilkan halaman utama, user milih menu registrasi, kemudian sistem akan menampilkan form registrasi, selanjutnya user mengisi form registrasi tersebut setelah selesai mengklik menu daftar dan kemudian sistem akan menampilkan id user yang telah di buat dan pendaftaran berhasil

(2). Activity Diagram Login

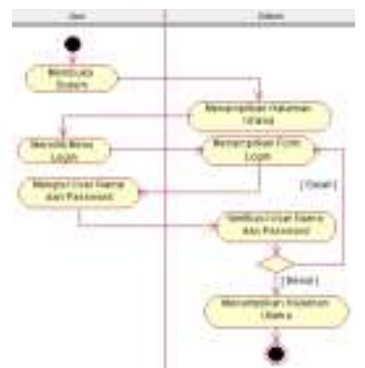

Gambar 3.12 Activity Diagram Login

Dijelaskan bahwa user membuka sistem, kemudian sistem menampilkan halaman utama, user memilih menu login, sistem kemudian menampilkan form login, user mengisi username dan password pada form login tersebut, sistem akan melakukan verifikasi username dan password jika sesuai maka sistem akan menampilkan halaman utama jika tidak sistem akan kembali form login lagi.

(3). Activity Diagram Merubah Profil

JURNAL ILMIAH TEKNOLOGI INFORMASI DAN KOMUNIKASI (JTIK) VOL 12, No.2, September 2021, pp. 74 - 83 


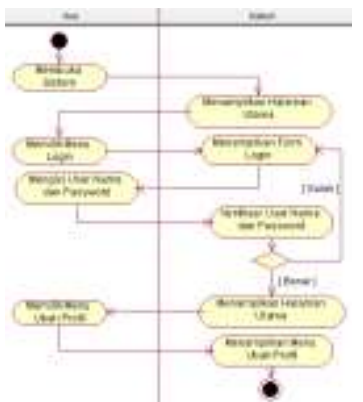

Gambar 3.13 Activity Diagram Merubah Profil

Dijelaskan bahwa user membuka sistem, kemudian sistem menampilkan halaman utama, user memilih menu login, sistem kemudian menampilkan form login, user mengisi username dan password pada form login tersebut, sistem akan melakukan verifikasi username dan password jika sesuai maka sistem akan menampilkan halaman utama jika tidak sistem akan kembali form login. Kemudian user memilih menu ubah profil selanjutnya sistem akan menampilkan menu ubah profil. (4). Activity Diagram Pembelian

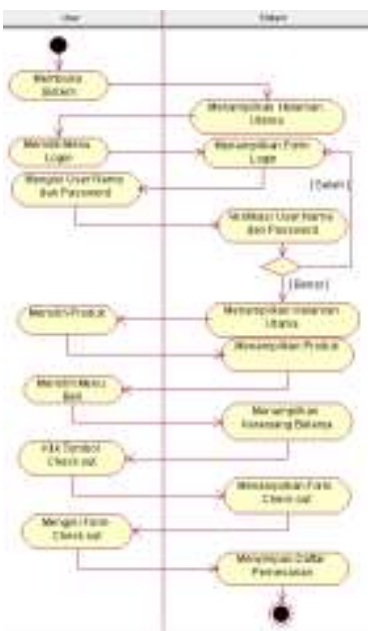

Gambar 3.14 Activity Diagram Pembelian

Dijelaskan bahwa user membuka sistem, kemudian sistem menampilkan halaman utama, user memilih menu login, sistem kemudian menampilkan form login, user mengisi username dan password pada form login tersebut, sistem akan melakukan verifikasi username dan password jika sesuai maka sistem akan menampilkan halaman utama jika tidak sistem akan kembali form login, selanjutnya user memilih produk, kemudian sistem menampilkan produk, user memilih menu beli selanjutnya sistem menampilkan keranjang belanja kemudian user klik tombol check out, sistem kemudian menampilkan form check out, kemudian selanjutnya user mengisi form check out, lalu sistem akan menyimpan daftar pembelian.

(5). Activity Diagram Lihat Produk dan Kategori

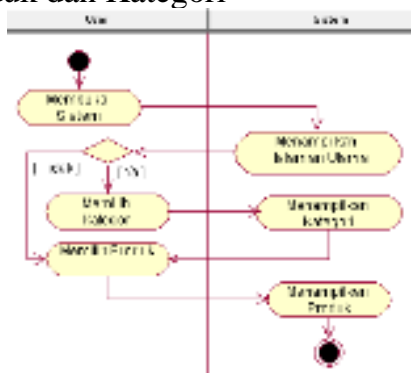

Gambar 3.15 Activity Diagram Lihat Produk dan Kategori

Dijelaskan bahwa user membuka sistem, kemudian sistem menampilkan halaman utama, user dapat memilih kategori sebelum memilih produk ataupun memilih produk langsung, jika memilih kategori, sistem akan menampilkan kategori, dan user akan memilih produk serta sistem akan menampilkan produk.

(6). Activity Diagram Admin 


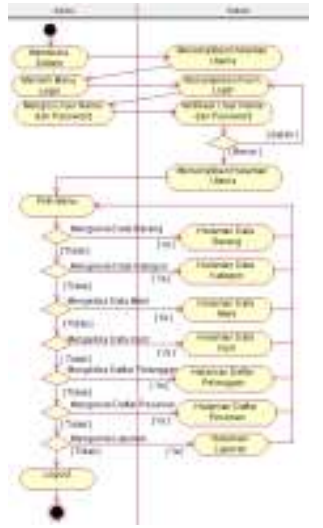

Gambar 3.16 Activity Diagram Admin

Dijelaskan bahwa admin membuka sistem, kemudian sistem menampilkan halaman utama, admin memilih menu login, sistem kemudian menampilkan form login, admin mengisi username dan password pada form login tersebut, sistem akan melakukan verifikasi username dan password jika sesuai maka sistem akan menampilkan halaman utama jika tidak sistem akan kembali form login, admin memlih menu kemudian sistem akan menampilkan halaman data produk, kategori, merk, kurir, daftar pelanggan, daftar pesanan dan laporan, selanjutnya admin memilih log out untuk keluar.

b. Perancangan Pemodelan Data

Menggambarkan relasi table dengan menggunakan ERD ( Entity Relationship Diagram ). 1.Entity Relationship Diagram (ERD)

Pembuatan Entity Relationship Diagram berkaitan antara data satu dengan yang lainnya. Seperti yang ditunjukkan pada gambar 3.17

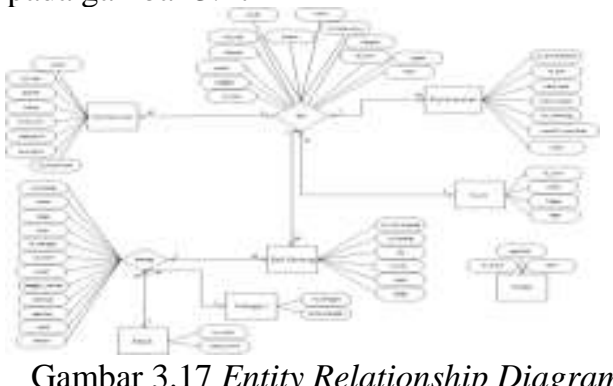

2.Perancangan Database

\section{Gambar 3.17 Entity Relationship Diagram}

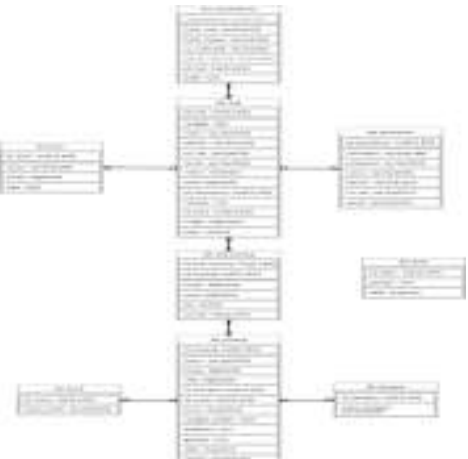

Gambar 3.18 Relasi tabel sistem informasi penjualan

\section{HASIL DAN PEMBAHASAN}

A. Kebutuhan Sistem Pendukung

Pada tahapan implementasi membutuhkan hardware dan software dengan spesifikasi yang telah ditentukan untuk membuat sistem informasi penjualan online berbasis web mobile pada PT XYZ, sebagai berikut :

1. Kebutuhan Hardware

JURNAL ILMIAH TEKNOLOGI INFORMASI DAN KOMUNIKASI (JTIK) VOL 12, No.2, September 2021, pp. 74 - 83 
81

Hardware yang digunakan dalam pembuatan sistem informasi penjualan online ini menggunakan spesifikasi komputer / laptop yang setara dengan processor intel Dual Core $2.4 \mathrm{Ghz}$, memory Ram DDR3 2GB, Harddisk 500GB, perangkat digunakan untuk melakukan pengujian sistem:

a. Smartphone iPhone $5 \mathrm{~S}$

b. Smartphone Polytron W6500

2. Kebutuhan Software

Software yang digunakan untuk membuat dan menjalankan rancang bangun sistem informasi penjualan online berbasis web mobile pada PT XYZ yaitu:

a. Web Server menggunakan Apache

b. Pemograman Web menggunakan PHP

c. Database menggunakan MySQL

\section{B. Implementasi Perancangan Sistem}

1. Tampilan antar muka (interface) konsumen (user)

a. Halaman Utama
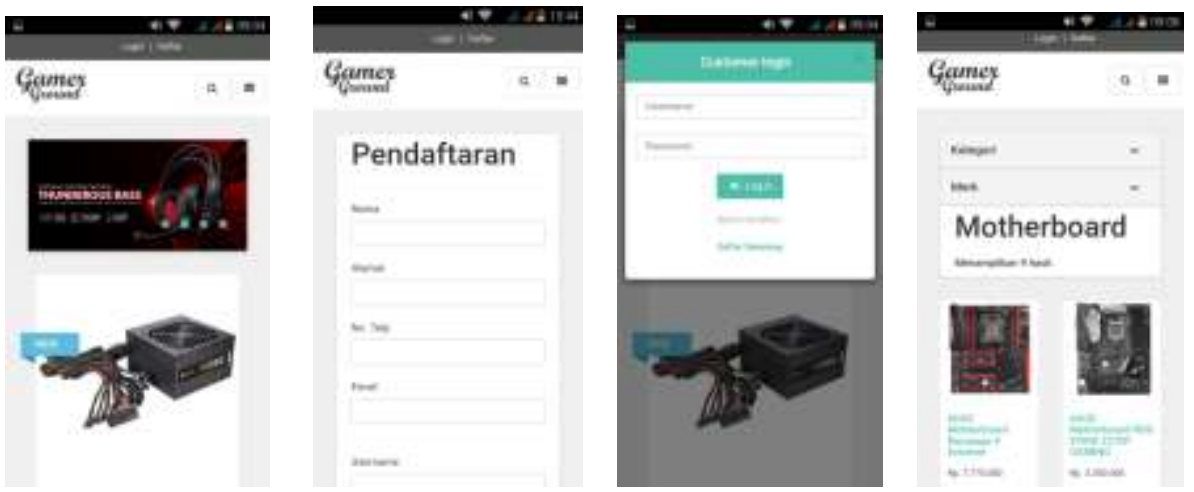

Gambar 4.12 Halaman Utama, Pendaftaran, Login dan Produk

b. Halaman Keranjang Belanja
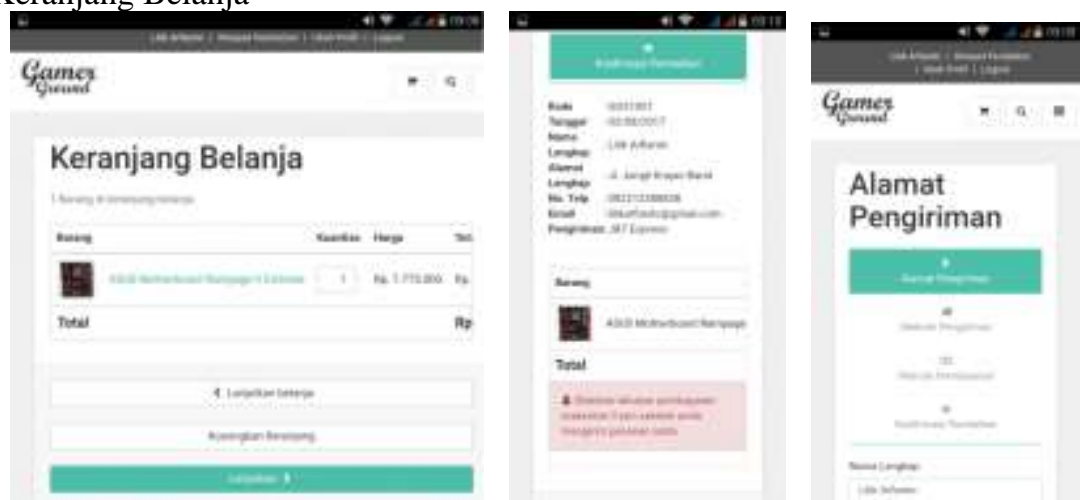

Gambar 4.16 Halaman Keranjang Belanja, Pembayaran dan Pengiriman

\section{Pembahasan}

Berdasarkan simulasi sistem informasi penjualan online berbasis web mobile pada PT XYZ . Berikutnya dilakukan pembahasan sistem, hasil, dan penilaian adalah sebagai berikut :

1. Rancang Bangun Sistem Informasi Penjualan Online berbasis web mobile yang telah dihasilkan dapat mempermudah konsumen dalam melakukan pembelian secara online, memudahkan konsumen dalam melihat produk-produk yang dijual, serta dapat memudahkan konsumen dalam melakukan konfirmasi pembayaran secara langsung melalui web.

Pada sistem yang lama masih menggunakan telepon dan sosial media dalam melakukan pemesanan produk. Sehingga terjadi beberapa masalah saat masih menggunakan sistem yang lama, yaitu: (1) ketidaksesuaian antara catatan stok dan jumlah barang yang tersedia, sehingga konsumen merasa kecewa terhadap pelayanan yang diberikan, (2) Masalah durasi tayang iklan di sosial media yang diunggah akan silih berganti dari satu tayangan konten produk ke konten produk yang lain dalam waktu yang relatif singkat, (3) Tidak adanya pengelolaan transaksi / nota penjualan konsumen sehingga 
terjadi pencatatan yang berulang-ulang, (4) Terjadi penurunan omset, dan (5) Manajemen data pelanggan yang kurang diperhatikan.

Dengan adanya sistem informasi penjualan online ini dapat mengatasi yang terjadi pada sistem yang lama, diantaranya : (1) Tidak terjadi nya ketidaksesuaian catatan stok dan jumlah barang, karena pada informasi produk telah ditampilkan stok barang yang tersedia. (2) Durasi tayang iklan yang relatif singkat yang sebelumnya ada pada sosial media, sekarang tidak ada lagi dengan cara membuat katalog produk, sehingga calon pembeli tidak kehilangan momentum melihat produk yang terpasang akibat durasi tayang yang relatif singkat. Seperti ditunjukkan pada gambar 4.15 (Halaman Produk) (3) Manajemen transaksi / nota penjualan yang lebih memudahkan admin dalam melakukan pengelolaan data transaksi / nota penjualan serta laporan penjualan di PT XYZ (4) Menajemen data pelanggan relatif lebih cepat dan terpusat, karena untuk melakukan pembelian produk harus mendaftar terlebih dahulu, sehingga data pelanggan yang telah terdaftar dapat dimanfaatkan untuk melakukan promosi terhadap pelanggan yang telah terdaftar melalui data pelanggan yang telah terdaftar. Sedangkan (5) Diharapkan dengan adanya sistem ini dapat meningkatkan omset penjualan pada PT XYZ .

2. Dihasilkan suatu sistem informasi yang dapat memudahkan admin dalam melakukan manajemen, diantaranya :

a. Manajemen data produk lebih mudah dilakukan, karena terdapat menu data barang yang memudahkan admin dalam memanajemen produk, diantaranya seperti (1) menambahkan produk (2) menghapus produk (3) mengedit produk. sehingga admin dapat mudah melakukan kontrol terhadap produk yang akan dijual. Seperti ditunjukkan pada gambar 4.21 (Halaman Data Produk).

b. Manajemen Data Pesanan lebih mudah dilakukan, karena saat konsumen melakukan pembelian produk, admin akan mengetahui bahwa terdapat pesanan baru yang masuk kedalam data pesanan, pada data pesanan tersebut admin dapat melakukan kontrol, dengan melakukan perubahan status pada pesanan yang telah dilakukan konsumen, melalui data pesanan tersebut admin dapat melakukan cek pada konfirmasi pembayaran yang telah dilakukan oleh konsumen. sehingga tidak terjadi lagi pencatatan yang berulang-ulang. Seperti ditunjukkan pada gambar 4.22 (Halaman Data Pesanan).

c. Manajemen data pelanggan lebih mudah dan relatif lebih cepat, karena data terpusat dan akan muncul pada data pesanan setelah konsumen melakukan pendaftaran, sehingga dapat memudahkan admin dalam melakukan promosi produk dengan menggunakan informasi data pelanggan yang telah tersedia, diantaranya dengan nomor telepon dan email. Seperti ditunjukkan pada gambar 4.23 (Halaman Data Pelanggan).

d. Manajemen Laporan lebih mudah dilakukan melalui menu laporan yang telah tersedia, sehingga admin dapat mengetahui laporan transaksi penjualan berdasarkan bulan ataupun tahun. Seperti ditunjukkan pada gambar 4.24 (Halaman Laporan).

Dengan adanya sistem informasi penjualan online berbasis web mobile ini manajemen data produk, data pesanan, data pelanggan, serta laporan lebih mempermudah admin dalam melakukan pengelolaan data pada PT XYZ semarang.

3. Dari Hasil penelitian yang telah dilakukan ini, dihasilkan suatu solusi untuk mengatasi masalah-masalah yang terjadi :

a. Penulisan nota yang berganda tidak terjadi lagi dikarenakan dari pembelian produk tersebut, akan masuk secara langsung ke dalam data pesanan sehingga penulisan nota yang berganda/berulangulang tidak terjadi. Seperti ditunjukkan pada gambar 4.22 Halaman Data Pesanan.

b. Kesalahan Kontrol Stok Barang dapat teratasi dengan adanya Data Barang yang ada pada sistem, sehingga saat akan melakukan input produk yang baru pada data barang tersebut terdapat kolom stok yang digunakan untuk menginput stok barang yang ada, yang dapat memudahkan kontrol stok barang. seperti gambar dibawah ini 4.25 Detail Data Barang.

c. Kesalahan Perhitungan Laporan Keuangan juga dapat diatasi dengan adanya halaman laporan dimana semua transaksi akan masuk pada halaman laporan, sehingga dapat memudahkan dalam melakukan perhitungan laporan keuangan pada PT XYZ . Seperti ditunjukkan pada Gambar 4.24 Halaman Laporan.

Dengan Adanya sistem informasi ini dapat mengatasi masalah penulisan nota yang berganda, kesalahan dalam melakukan kontrol stok barang, serta perhitungan laporan keuangan pada PT XYZ .

4. Dari Hasil Penelitian yang telah dilakukan juga didapatkan suatu proses yang lebih baik pada sistem yang baru diantaranya :

a. Konsumen dapat langsung melihat informasi produk yang mereka cari secara detail dibanding kan pada sebelumnya yang melalui telepon, karena saat melalui telepon konsumen hanya dapat mengetahui dari penjual yang menjelaskan barang saja, tidak secara detail, sehingga dengan di

JURNAL ILMIAH TEKNOLOGI INFORMASI DAN KOMUNIKASI (JTIK) VOL 12, No.2, September 2021, pp. 74 - 83 
sistem ini konsumen lebih cepat mendapatkan informasi produk yang mereka cari, Seperti ditunjukkan pada gambar 4.26 Detail Produk.

b. Konsumen pun dapat melakukan pembelian lebih cepat pada sistem ini karena saat konsumen melakukan pembelian produk, secara langsung akan masuk ke dalam data pesanan yang terdapat pada sistem dan dapat diketahui dengan cepat oleh admin PT XYZ yang akan melakukan konfirmasi dari pembelian yang telah dilakukan oleh konsumen, Seperti ditunjukkan pada gambar 4.22 (Halaman Data Pesanan).

\section{KESIMPULAN DAN SARAN}

A. Kesimpulan

Berdasarkan dari hasil dan pembahasan rancang bangun sistem informasi penjualan online berbasis web mobile pada PT XYZ, maka dapat disimpulkan sebagai berikut:

1. Sistem informasi penjualan online berbasis web mobile ini dapat memudahkan proses pembelian lebih cepat dan mudah dibandingkan menggunakan telepon dan sosial media.

2. Adanya sistem informasi penjualan online berbasis web mobile ini dapat mengurangi masalah yang terjadi pada PT XYZ semarang, diantaranya : (1) Manajemen stok lebih baik dikarenakan manajemen data produk baru lebih mudah, (2) Durasi tayang iklan yang relatif singkat sudah dapat teratasi dengan cara membuat katalog produk, (3) Pencatatan berulang-ulang tidak terjadi lagi dengan adanya pengelolaan data pesanan, (4) manajemen data pelanggan lebih diperhatikan dengan adanya pengelolaan data pelanggan dan (5) Laporan transaksi penjualan lebih mudah dilakukan dengan adanya pengelolaan data laporan

B. Saran

Berdasarkan dari hasil uraian pembahasan serta kesimpulan tersebut, agar sistem dapat memberikan pelayanan yang lebih baik disarankan dalam penelitian ini yaitu :

1. Sistem informasi penjualan online berbasis web mobile pada PT XYZ dapat ditambahkan pembayaran melalui "credit card" dengan bekerja sama dengan bank yang bersangkutan, dan penambahan sistem keamanan pembayaran untuk meningkatkan kenyamanan dalam melakukan transkaksi pembayaran secara online.

2. Sistem informasi penjualan online berbasis web mobile pada PT XYZ dapat dikembangkan menjadi berbagai aplikasi berbasis android dan ios.

\section{DAFTAR PUSTAKA}

[1] Amsyah, Zulkifli. 2010. Manajemen Sistem Informasi. Jakarta

[2] Hizair, MA. 2013. Kamus Lengkap Bahasa Indonesia. Jakarta: TAMER.

[3] Kadir, Abdul. 2014. Pengenalan Sistem Informasi Edisi Revisi. Yogyakarta: Andi.

[4] Kroski, Ellyssa. 2008. On the Move with the Mobile Web: Libraries and Mobile Technologies - What Is the Mobile Web?. Library Technology Reports, [online] : www.techsource.ala.org, [27 Agustus 2017].

[5] Nugraha, Rikky Wisnu dan Budiman, Asep Syarip. 2014. Perangkat Lunak Pemesanan Pembuatan Software CV Valiodological \& Feeling Berbasis Web. Bandung : Jurnal LPKIA, Vol 1, No. 1

[6] Nugroho, Adi. 2010. Rekayasa Perangkat Lunak Menggunakan UML \& Java. Yogyakarta: Andi Offset.

[7] Prabowo, Pudjo Widodo. 2011. Menggunakan UML. Informatika. Bandung.

[8] Pressman, R.. 2010. Software Engineering A Practitioner's Approach th Edition. Unites States : Mc

[9] Ristono, Agus. 2009. Manajemen Persediaan. Yogyakarta : Graha Ilmu

[10] Sugiono, Arief., Yanuar Nanok Soenarno dan Synthia Madya Kusumawati, 2010. Akuntansi \& Pelaporan keuangan: untuk bisnis sekala kecil dan menengah, Jakarta: Grasindo.

[11] Sulistiyowati, Leny. 2010. Panduan Praktis Memahami Analisis Laporan Keuangan, Jakarta: PT Elex Media Komputindo.

[12] Supriyanto, Aji. 2007. Pengantar teknologi informasi. Jakarta : Salemba Infotek.

[13] Sutabri, Tata. 2012. Konsep Dasar Informasi. Yogyakarta: Andi Offset.

[14] Sutarman. 2012. Pengantar Tekhnologi Informasi, Jakarta: Bumi Aksara

[15] Williams, B.K. and Sawyer, S.C. 2011. "Using Information Technology: A Practical Introduction to Computers \& Communications. (9th edition)". New York: McGraw-Hill.

[16] Wong, Jony. 2010. Internet Marketing for Beginners, Elex Media Komputindo, Jakarta.

[17] Yakub. 2012. Pengantar Sistem Informasi, Yogyakarta: Graha Ilmu. 